\title{
建设师德师风，提高 “课程思政”成效
}

\section{To improve the effectiveness of Ideological and political education in the course by building teachers' ethics and style}

\author{
刘艳 \\ Yan Liu \\ 宁夏职业技术学院软件学院 中国·宁夏 750002 \\ Ningxia Polytechnic software college, Ningxia, 400020, China
}

\begin{abstract}
摘 要: “棵程思政”作为高职院校落实立德树人的根本性举措, 以棵堂教学为切入点, 所有教师都是“棵程思政”的实施者, 而教师的育德意识，坚定的理想信念、道德情操、扎实学识、仁爱之心这些高尚的师德师风才是 “课程思政”工作顺利实施、 提高成效的重要保障。
\end{abstract}

\begin{abstract}
: "curriculum ideological and political" as a fundamental measure to implement moral education in higher vocational colleges, taking classroom teaching as the starting point, all teachers are the implementers of "curriculum ideological and political" , and teachers' moral education consciousness, firm ideal and belief, moral sentiment, solid knowledge, and benevolence are the noble teachers' ethics and teachers' style, which are the smooth implementation and improvement of the effectiveness of “curriculum ideological and political” work security.
\end{abstract}

关键词：课程思政；育德意识；理想信念；道德情操；扎实学识；仁爱之心

Key words : Ideological and political education; moral education consciousness; ideal and belief; moral sentiment; solid knowledge; benevolence

DOI: $10.36012 /$ sde.v2i12.2565

“培养什么人、怎样培养人、为谁培养人” 是习近平总 书记在 2016 全国高校思想政治工作会议上提出的高校教育 的根本问题, 会议上强调要坚持把立德树人作为中心环节, 把思想政治工作贯穿教育教学全过程, 实现全程育人、全方 位育人，努力开创我国高等教育事业发展新局面。高校思想 政治教育提出的 “课程思政”, 是 “怎样培养人” 的重要举 措, 是构建德智体美劳全面培养的教育体系和高水平人才培 养体系的有效切人，也是完善全员全程全方位 “三全育人” 的重要抓手。

高等职业教育在国家高等教育中发挥着越来越重要的 作用，以立德树人为根本，培养德智体美劳全面发展的高技 能人才。在高职院校, 之前更多的强调培养学生的专业技能, 重教学, 轻育人, 尤其部分教师来自企业, 更是只关注学生 知识技能的掌握, 对于育德不太在意, “课程思政” 被认为
是额外的任务。目前, 虽然各学校积极贯彻响应“课程思政”, 但重点在主抓课程的 “思政” 设计, 课程的设计固然重要, 但设计能否顺利实施, 取得相应的成效, 与教师本身育德意 识和师德师风有很大的关系。作为高职院校的一线教师, 在 “课程思政” 实施的过程中, 深切感受到, 师德师风建设是 “课 程思政” 工作实施的基石，同样 “课程思政”工作对师德师 风建设有很好的促进作用，也对老师的教育教学思想有一 定的转变。

\section{1 提高教师的育德意识}

让教育者先受教育。目前需要改变部分教师的一些认 识 : 自己只管传授知识与技能, 其他与己无关。例如, 学 生课堂的其他行为不管不顾, 或者去找辅导员让处理。要 让每个教师清晰的认识到“课程思政”是完善 “三全育人”

【作者简介】刘艳（1971 )，女，宁夏中宁县人，大学，教授。 
的重要方面。“课程思政”不是哪一门课或哪一个部门的事 情, 而是一项为党育人为国育才的系统工程 ${ }^{[1]}$ 。它强调包 括思想政治理论课在内的所有课程都有育人功能, 所有教 师都有育人职责。推进 “课程思政” 建设是全体教职工的 共同责任，涉及教育教学全过程各方面。让每一位教师明 白 “课程思政” 的意义 ${ }^{[2]}$, 明确 “课程思政” 是义不容辞的 责任。

还有一些教师因为学校的要求, 进行 “课程思政”工 作, 认为只需要在课程设计上下功夫即可。平时上课的随 意, 言行举止的漫不经心, 下课后, 一走了之, 不与学生 有课后的任何互动, 甚至不以教师的职业道德去要求自己, 又如课程中设置了思政目标: 严谨规范, 但在展示案例的 时候, 自己却随意书写等, 这样你设计的越好, 学生的疑 问会越多, 产生怀疑, 说教的越多, 反倒会起到更不好的 作用, 亲起师, 才能信其道。这些行为实质上是教师师德 师风的问题，让老师们成为 “四有” 好老师。才可以顺利 有效的推进 “课程思政”, 让 “课程思政”工作取得应有的 成效。

\section{2 教师要有崇高的理想信念才能实现 “立 德树人 “的培养目标}

新时代高等职业教育发展的新任务就是培养社会主义 建设者和接班人, 要坚决拥护中国共产党领导, 树立中国特 色社会主义共同理想, 践行社会主义核心价值观。教师首先 要有坚定的理想信念。理想信念, 是好老师的人格基石。教 师是人类文明的传递者、学生人生道路的引路人。有什么样 的教师, 就有什么样的教育, 有什么样的教育, 就有什么样 的学生 ${ }^{3}$ 。每个有理想, 有追求的教师, 以 “传道” 为第一 责任和使命, 培养学生的家国情怀, 为学生点燃梦想, 让学 生有正确的 “三观”、准确的政治站位、符合社会发展的道 德评判、基本的文化素养。在价值取向多元化的时代，一个 有理想信念的好老师, 是社会主义核心价值观的带头践行者 和传播者, 核心价值观根植于一个民族的历史文化传统的土 壤之中。道路自信、理论自信, 制度自信的基础是文化自信。 教师应该有文化自觉，了解、欣赏乃至热爱中华民族优秀的 传统文化, 对 “去中国化” 保持高度警觉。教师亦是核心价 值观的传播者, 为莘莘学子把好人生的 “总开关”, 扣好人
生的第一颗 “扣子”, 就能为党和国家事业造就大批理想远 大、信念坚定的合格人才, 为实现民族复兴的伟大梦想输送 源源不断的生力军 ${ }^{[4]}$ 。

\section{3 教师要有高尚的道德情操才能培养学生 的优秀品格}

教师对学生的影响, 离不开教师的学识和能力, 更离 不开教师待人处事, 对国家对民族、对公对私所持有的价值 观。习近平总书记说过 : 一个教师如果在是非、曲直、善 恶、义利、得失等方面老出问题，怎么能担当起立德树人的 责任? 广大教师必须率先示范、以身作则。要求学生做到 的自己首先要做到, 教师的一言一行, 一举一动, 在不经 意间都会影响到学生, 教师要用自己的人格魅力来熏染学生 的行为, 引导和帮助学生把握好人生方向。好老师应该执着 于教书育人, 我们常说, 干一行爱一行, 如果身在学校, 心 却在商场或官场，在金钱、物语、名利同人格的较量中把 持不住自己, 那是当不好老师的 ${ }^{[5]}$ 。教师要做好学生灵魂的 工程师, 首先要有高尚的道德情操, 才能以德治教, 以德 育人。

\section{4 教师扎实的学识才能培养学生适应社会 需求的专业技能}

扎实的知识功底, 过硬的教学能力, 勤勉的教学态度, 科学的教学方法是的基本素质, 其中知识是根本基础。高职 院校主要培养高水平技术技能型人才, 教师扎实的学识, 丰 富的实践经验才能满足学生的需求, 促进学生的学习发展和 自身的专业成长。如果教师专业知识不扎实、缺乏实践经验, 教学中必然会捉襟见时, 更谈不上游刃有余, 学生则不信服 教师, 如何教育学生?

随着信息技术高速发展、经济全球化进程加快，社会 需要具备灵活性、适应性、自主性、合作能力以及创新精神 的高素质人才。所以好老师应树立终身学习理念, 不断汲取 并灵活运用新知识。还要引导学生掌握正确的学习方法, 不 断探索的精神, 才是走出校园的强身技能。好老师不能满足 于装满自己的 “一桶水”, 而要使自己时时有 “活水”, 与时 俱进, 不断汲取新知识, 更新自己的知识结构, 积极回应新 的挑战, 追求卓越。只有这样, 教师才能站在知识发展的前 
沿, 实现自身的长远发展, 并引导学生走向未来发展的人生 之路 ${ }^{[6]}$ 。

\section{5 教师的仁爱之心开启学生的心灵之门}

教育是一门 “仁而爱人” 的事业, 做好教师, 要有仁 爱之心, 没有爱心的人不可能成为好教师。教师的仁爱之心 是一种无私的爱、不求回报的爱。教师的仁爱之心是以师 生相互信赖为基础的，这种信赖是尊重、理解和关怀 ${ }^{[7]}$ 。目 前, 高职多为中职学生或较本科院校录取分数线低很多的 高考学生, 大多不喜欢学习, 敏感不自信, 之前的学习经 历, 大多对老师近而远之, 他们渴望被人尊重、信任和理解, 但又表现的无所谓。对于这些学生其实老师的一点关心和 关注, 都会使学生有所触动。所以高职的老师更要善于 发现学生身上的内光点, 激励学生的上进心与志趣。尊重 学生的人格, 尊重学生的发展规律, 不要根据教师的好恶 来评判学生的好坏。教师一定要相信学生, 使学生从信任 中产生自信, 唤起自省、自悟、自尊, 激发其不断的进取 精神。

高职学生中, 有不少的孩子学习有困难, 家庭问题也 不少, 表现就是啥时候都不吭声, 老师课间或课下多关心 一下学生的学习、生活、思想等方面, 老师送去的问候与 关怀, 就会使学生受感动, 产生对教师的亲近感和仰慕心 理, 从而乐于接受教师的教育。当然一定要严格要求学生, 严格要求学生是更高层次的爱, 要对学生松解、懒散的行 为进行约束。公正地对待学生, 对学生不论成绩好坏, 品 德优劣, 都要平等相待, 付出同样的爱。尤其对后进生不 仅不歧视, 反而要加倍地 “偏爱”, 要付出更多的爱, 这份 爱往往会促使他们充满信心, 去战胜自我, 重新塑造自我。 教师只有爱岗敬业, 无私奉献, 才能在平凡的岗位上做出不 平凡的业绩, 从而赢得社会的尊重和学生的爱戴。若因为 一点私利, 便满腹牢骚, 付出一点, 就要回报, 如何去教 育学生? 教师只有以身立教, 为人师表, 才能树立起良好 的教师形象, 成为学生学习的楷模, 从而达到教育学生的 目的。

教师有了坚定的理想信念、崇高的道德情操、扎实学识、 仁爱之心这些高尚的师德师风，“课程思政”工作的实施则 有了保障, 再提高教师的育德能力, “课程思政” 就会顺利
有效进行。关于师德师风建设和提高教师的育德能力, 有两 点建议:

\section{1 加强教师党支部建设}

从加强教师党支部建设着手, 发挥教工党员的模范带 头作用, 站到立德树人的第一线, 以实际行动带动全体教职 工, 统一思想, 提高认识, 共同抓好教学工作, 提升 “课程 思政”工作的质量。具体措施如下：

（一）支部成员坚持学习贯彻习近平新时代中国特色社 会主义思想，使之系统权威进教材、生动有效进课堂、刻骨 铭心进头脑, 厚植于广大师生心中。坚持每天的 “学习强国” 平台学习，增强 “四个意识”、坚定 “四个自信”，树牢 “两 个维护”。巩固拓展 “不忘初心，牢记使命” 主题教育成果， 将 “两学一做” 学习教育活动常态化制度化, 认真组织 “三 会一课”、组织生活会、民主生活会和主题党日活动。加强 对积极要求入党的同志的培养教育，把优秀的年轻骨干教师 吸收到党组织中。

（二）以理想信念为人格基石, 开展 “树立理想信念, 做幸福之师” 专题大讨论活动, 帮助教师疏导心理情绪、消 除职业倦急，打造有感恩情怀、专业认同感、职业幸福感的 幸福之师; 以道德情操为核心品质,建立 “学习社团、职教圈、 职教俱乐部” 等教师专业成长的 “精神家园”, 引导广大教 师正其语、美其行、修其身，打造能见贤思齐、以德立身的 模范之师。

（三）强化责任担当,突出育人职责。在 “三全育人”、“课 程思政”、“疫情防控”等重点工作中，党员教师都要起到模 范带头作用。比如通过支部党员联系班级、指导班级 “此时 此刻我想对祖国说”、线上专业教学中融入 “疫情防控知识” 的教育内容、与学生谈心谈话、组织并参加学生丰富多彩的 文体活动等方式, 引导学生做社会主义核心价值观的坚定信 仰者、积极传播者、模范践行者。

(四) 支部发挥模范带头作用, 在学院的 “双高” 建设中, 不怕困难, 知难而上。敢作为, 有创新。

（五）教工支部要加强与群众教师、学生的联系沟通, 解决学生中的困难和问题, 支部成员以身作则起带头作用, 团结全员师生，让全院上下展现团结友爱、互助和谐、朝气 蓬勃、积极向上的良好精神风貌。

(下转第 7 页) 
习过程中的问题, 并可以及时解决 ; 第二, 教师需要将学生 每个阶段的检测成绩都计入到学生的平时成绩中, 避免学生 为了应付期末考试, 只在最后阶段进行突击学习。学生也可 以通过阶段性的检测来发现自己身上的问题, 在后期的学习 中可以有针对性的改进 ; 第三, 教师需要明确教学评价的侧 重点, 重点需要对学生在职位岗位上的实际英语应用能力进 行考核。同时,教师需要注意的是对于考核结果较差的学生, 教师需要加强鼓励和指导, 避免打击学生的学习信心。

\section{3 构建 “双师型”专业英语教师队伍}

高职院校需要加强对民航英语教师的培训, 构建 “双 师型” 专业英语教师队伍, 这也是培养民航专业人才的要求。 首先, 高职院校需要适当提高民航专业英语教师的招聘门 槛, 不仅需要对应聘者的学历进行考核, 还需要对其专业知 识和教学能力等进行考察。同时, 民航英语教师还需要对民 航专业有一定的了解, 进而在实际的教学过程中可以结合当 前的民航事业的发展进行有针对性的教学; 其次, 高职院校
需要加强对民航专业英语教师的培训, 为其提供参加课程培 训和项目合作的机会, 挖掘教师自身的潜力 ; 最后, 高职民 航英语教师之间也需要定期的进行交流, 实现同事之间的相 互促进 [3]。

\section{4 结束语}

综上所述, 民航英语教学需要以实际工作过程为指导, 结合具体的岗位要求进行教学, 如此方能提高学生的英语应 用能力, 满足民航事业对人才的要求。

\section{参考文献}

[1] 董巍.民航英语教学现状分析与改进策略 [J]. 中国新通 信 , 2018,020（014）:201.

[2] 曲茹. 高职院校民航英语教学现状分析及改进策略 [J]. 农家参 谋, 2019,619 ( 10 ) :295.

[3] 拱雕, 顾灿. 航空英语教学中的问题与改进方法研究 [J]. 文洲: 小学版, 2019,000 (001):724.

\section{(上接第 10 页)}

\section{2 充分发挥一些 “好老师” 的榜样作用}

（一）让所有教师参加诸如 “厚植爱国情怀，涵育高尚 师德, 加强新时代教师队伍建设” 之类的专题培训, 学习全 国在德育方面做出突出贡献的一线教师的事迹，参加宣扬高 尚师德师风的讲座, 这些讲座给老师的启发和教益是丰富、 深刻和长久的, 会影响、感染老师们去反思自己的教学理念, 改变自己的教学方法。

（二）发挥教研室 “好老师” 的模范带头作用

一些德才兼备的教师在没有进行 “课程思政 “工作之前, 其实在教学中一直在无意识的进行育人工作, 通过” 课程思 政 “工作有无意识变为有设计，有片段化变为系统性，偶发 性变为常态, 挖掘课程中的思政元素, 将知识传授与价值引 领有效结合, 实现立德树人的润物无声。有计划的组织教研 室活动, 让他们带动其他教师进行教学活动。由点到面, 让 所有教师都行动起来，全面、系统实施 “课程思政”，提高 教师的育德能力。当老师行动起来的时候, 学生就会有变化, 老师会有意外的收获。职业的成就感油然而生, 将会更加热 爱自己的事业。
结语 : 高职院校在大力推进 “课程思政”, 加快培养德 智体美劳全面发展的高层次创新型人才。让我们每一位教师 如德国哲学家雅斯贝尔斯说过的 “一棵树摇动另一棵树, 一 朵云推动另一朵云, 一个灵魂唤醒另一个灵魂 “。从而培 养一代又一代社会主义建设者和接班人, 为实现中国梦增添 强大青春能量。

\section{参考文献}

[1] 韩宪洲. 深刻认识 “课程思政” 的时代价值（凭栏处） [N]. 人 民日报，2019-08-18

[2] 韩宪洲. 深化 “课程思政”建设需要着力把握的几个关键问题 $[\mathrm{N}]$. 北京联合大学学报 (人文社会科学版) ,2019-08-18

[3]评论员文章. 好老师要有理想信念 [N]. 中国教育报, 2014-9-11

[4] 评论员文章. 好老师要有理想信念 [N]. 中国教育报, 2014-9-11

[5] 吴江萍. 论师范生廉洁从教思想素质的培养 [N]. 桂林师范高等 专科学校学报, 2015

[6] 评论员文章. 好教师要有扎实学识 [N]. 中国教育报, 2014-9-15

[7] 好老师要有仁爱之心——学习贯彻习近平总书记教师节重要 讲话精神 [J].教育文化论坛 2014,6（05）,140 